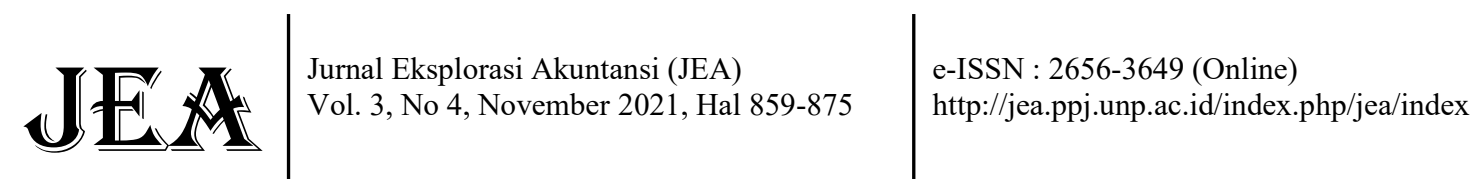

\section{Pengaruh Kesadaran Wajib Pajak, Kualitas Pelayanan dan Tingkat Penghasilan Terhadap Kepatuhan Pembayaran Pajak Bumi Bangunan}

\author{
Irfan Donofan ${ }^{1 *}$, Mayar Afriyenti ${ }^{2}$ \\ ${ }^{1,2}$ Fakultas Ekonomi, Universitas Negeri Padang \\ *Korespondensi: ipandono58@gmail.com
}

\begin{abstract}
The purpose of this study was to determine the effect of taxpayer awareness, service quality and income rate on land and building tax payment compliance in Payakumbuh. Researchers distributed questionnaires to Land and Building Taxpayers registered with the Regional Finance Agency with a total sample of 100 samples using the convenience sampling method. The results showed that taxpayer awareness and service quality had a positive and significant effect on compliance with land and building tax payments with a significance value of 0.001 and 0.000 which were smaller than 0.05. Meanwhile, income rate has no effect on compliance with land and building tax payments with a significance value of 0.162 greater than 0.05. Recommendations for further research are expected to use other independent variables that are considered relevant to the research and use different sampling methods such as using the cluster sampling method.
\end{abstract}

Keywords : Income; Service Quality; Taxpayer Awareness; Taxpayer Compliance.

How to cite (APA $6^{\text {th }}$ style)

Donofan, Irfan \& Afriyenti, Mayar. (2021). Pengaruh Kesadaran Wajib Pajak, Kualitas Pelayanan dan Tingkat Penghasilan terhadap Kepatuhan Pembayaran Pajak Bumi Bangunan. Jurnal Eksplorasi Akuntansi (JEA), 3 (4), 859-875.

\section{PENDAHULUAN}

Pengumpulan pajak yang dilakukan oleh pihak fiskus atau pemerintah mempunyai kendala, salah satunya masih rendah tingkat kepatuhan wajib pajak yang disebabkan adanya anggapan pajak bukan kewajiban karena tidak mendapatkan manfaat dari pembayaran pajak tersebut (Budhiartama dan Jati, 2016). Kepatuhan diartikan sebagai tindakan tunduk terhadap suatu keadaan atau aturan. Kepatuhan dalam perpajakan berarti tindakan patuh dalam melaksanakan kewajiban perpajakan sesuai dengan peraturan perundang-undangan perpajakan. Kepatuhan perpajakan diartikan sebagai suatu keadaan dimana wajib pajak memenuhi semua kewajiban perpajakan dan melaksanakan hak perpajakannya (Rahayu, 2010).

Kepatuhan wajib pajak yang tinggi diperlukan mengingat penerimaan pajak sangat penting untuk menjalankan kegiatan pemerintahan, karena tanpa adanya penerimaan yang cukup maka program-program pemerintah akan berjalan secara tidak maksimal karena salah satu sumber penghasilan yang besar adalah pajak. Kepatuhan wajib pajak yang rendah akan mengurangi penghasilan yang diterima dan menyebabkan pajak kurang diandalkan sebagai 
sumber pendapatan, karena itu kepatuhan wajib pajak perlu diperhatikan dan ditingkatkan (Septarini, 2015).

\section{Tabel 1}

Daftar Anggaran dan Realisasi Penerimaan Pajak Bumi dan Bangunan (PBB) di Kota Payakumbuh Tahun 2014-2020.

\begin{tabular}{|c|c|c|c|c|c|c|c|}
\hline \multirow[b]{2}{*}{ No } & \multirow[b]{2}{*}{ Tahun } & \multirow{2}{*}{ Anggaran } & \multicolumn{4}{|c|}{ Realisasi Penerimaan } & \multirow[b]{2}{*}{$\%$} \\
\hline & & & Piutang & Denda & Pokok & $\begin{array}{c}\text { Total } \\
\text { Penerimaan }\end{array}$ & \\
\hline 1 & 2014 & 2.850 .404 .871 & 310.769 .741 & 207.332 & 1.871 .073 .140 & 2.182 .050 .213 & 76,55 \\
\hline 2 & 2015 & 2.666 .908 .102 & 165.231 .699 & 12.739 .483 & 1.744 .588 .245 & 1.922 .559 .427 & 72,09 \\
\hline 3 & 2016 & 2.670 .630 .305 & 183.295 .230 & 9.890 .310 & 1.437 .528 .199 & 1.630 .713 .739 & 61,06 \\
\hline 4 & 2017 & 2.680 .509 .237 & 262.770 .234 & 5.668 .064 & 1.584 .173 .127 & 1.852 .611 .425 & 69,11 \\
\hline 5 & 2018 & 2.703 .238 .183 & 244.881 .773 & 13.696 .710 & 1.482 .241 .710 & 1.740 .820 .193 & 64,40 \\
\hline 6 & 2019 & 2.725 .689 .964 & 614.828 .489 & 5.571 .601 & 1.428 .825 .249 & 2.049.225.339 & 75,18 \\
\hline 7 & 2020 & 2.856 .656 .814 & 613.483 .151 & 17.824 .261 & 1.277.239.287 & 1.908.546.699 & 66,81 \\
\hline
\end{tabular}

Sumber: Badan Keuangan Daerah Kota Payakumbuh (2021).

Data Badan Keuangan Daerah Kota Payakumbuh mengenai realisasi penerimaan pajak bumi bangunanan dari rentang tahun 2014 sampai dengan 2020 secara keseluruhan mengalami fluktuasi yang terkadang naik dan kemudian turun kembali yang dapat dilihat dari persentase realisasi terhadap anggaran penerimaan yang telah ditetapkan. Hal ini dapat dilihat dari anggaran dan realisasi penerimaan pajak bumi bangunan Kota Payakumbuh dari tahun 2014 sampai 2016 turun dari 76,55\% menjadi 61,06\% dengan realisasi penerimaannya turun dari Rp 2.182.050.213 menjadi Rp 1.630.713.739. Pada tahun 2017 kembali naik menjadi $69,11 \%$ dengan realisasi penerimaan sebesar Rp 1.852.611.425, sedangkan pada tahun 2018 realisasi penerimaan PBB kembali turun menjadi $64,40 \%$ kemudian naik kembali pada tahun 2019 sebesar 75,18 dan pada tahun 2020 kembali turun menjadi 66,81\%.

Hal ini menunjukkan bahwa tingkat kepatuhan wajib pajak Kota Payakumbuh masih belum stabil dan menyebabkan rendahnya serapan pajak bumi bangunan. Kepatuhan wajib pajak yang belum stabil disebabkan oleh beberapa faktor yang memberikan dampak pada wajib pajak untuk patuh menjalankan kewajibannya sebagai wajib pajak.

Kepatuhan wajib pajak dalam melaksanakan kewajiban perpajakan dipengaruhi oleh beberapa faktor yang terdiri dari kesadaran wajib pajak, pengetahuan wajib pajak, kualitas pelayanan, tingkat penghasilan dan persepsi wajib pajak terhadap sanksi perpajakan (Yusnidar, 2016). Kesadaran wajib pajak merupakan tindakan sadar maupun sukarela yang dilakukan wajib pajak. Kesadaran wajib pajak adalah kondisi di mana wajib pajak mempunyai pengetahuan dan pemahaman mengenai perpajakan, serta mempunyai kesungguhan dan keinginan untuk mematuhi kewajiban perpajakannya tanpa ada paksaan dari pihak lain. Kesadaran wajib pajak yang tinggi diikuti dengan tingginya tingkat kepatuhan wajib pajak dalam hal pembayaran kewajiban perpajakannya (Muliari dan Setiawan, 2010).

Berdasarkan penelitian yang telah dilakukan oleh Takaria dan Siregar (2020) menyatakan bahwa kesadaran wajib pajak berpengaruh terhadap kepatuhan wajib pajak, sejalan dengan hasil penelitian Rahman (2018) bahwa kesadaran wajib pajak mempunyai pengaruh terhadap kepatuhan pembayaran pajak bumi bangunan. Hal ini bertentangan dengan hasil penelitian Lydiana (2018) dan Pravasanti (2020) yang menunjukan kesadaran wajib pajak tidak berpengaruh pada kepatuhan wajib pajak.

Pemerintah juga mempunyai peran yang sangat penting dalam terwujudnya kepatuhan wajib pajak dalam pembayaran pajak, salah satunya dengan memberikan kualitas pelayanan yang baik dan memadai oleh pihak fiskus kepada wajib pajak. Pelayanan yang diberikan bukan hanya secara sistem, tetapi juga pelayanan dalam bentuk pihak fiskus mempunyai 
keahlian serta pengetahuan mengenai perpajakan. Pelayanan yang diberikan oleh pihak fiskus mempunyai dampak terhadap kepatuhan wajib pajak, semakin baik tingkat kualitas pelayanan perpajakan yang diberikan oleh pihak fiskus akan mengakibatkan wajib pajak merasa nyaman dalam melakukan pembayaran pajak sehingga tingkat kepatuhannya juga semakin tinggi (Santika, 2015). Berdasarkan penelitian yang telah dilakukan Mahardika et al (2015) dan Isawati et al (2016) menyatakan bahwa kualitas pelayanan berpengaruh terhadap kepatuhan wajib pajak. Namun, berbeda dengan penelitian yang dilakukan oleh Endaryanti (2017) dan Tulenan et al (2017) bahwa kualitas pelayanan tidak berpengaruh terhadap kepatuhan wajib pajak.

Faktor lain yang memengaruhi kepatuhan wajib pajak adalah tingkat penghasilan wajib pajak. Penghasilan dapat diartikan sebagai salah satu bentuk balas jasa yang diterima dikarenakan sudah menyelesaikan suatu pekerjaan. Pada dasarnya semakin tinggi penghasilan seseorang maka kepatuhan sebagai wajib pajak juga akan tinggi. Apabila tingkat penghasilan wajib pajak tinggi maka ia bisa memenuhi kebutuhannya dan juga untuk melaksanakan kewajibannya untuk membayar pajak dan begitupun sebaliknya apabila penghasilan yang diperoleh rendah maka untuk melaksanakan kewajiban perpajakan akan terhambat oleh kebutuhan dan tuntutan ekonomi lainnya (Haswidar, 2016). Berdasarkan penelitian yang dilakukan Amran (2018) menyatakan bahwa tingkat penghasilan berpengaruh terhadap kepatuhan wajib pajak, sejalan dengan penelitian yang dilakukan Ezer dan Ghozali (2017) bahwa penghasilan wajib pajak mempunyai pengaruh terhadap kepatuhan wajib pajak. Namun, berbeda dengan hasil penelitian Rahman (2018) dan Isawati et al (2016) menyatakan bahwa tingkat penghasilan tidak berpengaruh terhadap kepatuhan wajib pajak.

Penelitian ini bertujuan untuk memberikan bukti teori atribusi dengan melakukan pengujian terhadap variabel kesadaran, kualitas pelayanan dan tingkat penghasilan terhadap kepatuhan wajib pajak. Penelitian ini merupakan pengembangan dari penelitian yang dilakukan oleh Takaria dan Siregar (2020) mengenai kesadaran wajib pajak terhadap kepatuhan pajak bumi bangunan. Peneliti ingin melakukan pengujian kembali di Kota Payakumbuh tahun 2021, dengan menambahkan variabel kualitas pelayanan dan tingkat penghasilan dari penelitian yang dilakukan oleh Asriani dan Susena (2016), pada penelitian tersebut ditemukan hasil kualitas pelayanan dan tingkat penghasilan yang tidak berpengaruh terhadap kepatuhan wajib pajak.

\section{REVIU LITERATUR DAN HIPOTESIS}

\section{Teori Atribusi}

Teori Atribusi dikemukakan oleh Fritz Heider seorang psikolog jerman. Teori ini menjelaskan tentang motif seseorang untuk bertindak atau berperilaku. Teori atribusi memberikan pandangan bahwa motif yang didasari untuk bertindak atau berperilaku bisa disebabkan oleh faktor internal maupun eksternal. Faktor internal untuk melakukan sesuatu bisa berasal dari niat, kesadaran dan sifat. Sedangkan faktor eksternal bersumber dari tekanan pihak lain maupun lingkungan sosial sekitar (Nisa, 2017).

Atribusi terhadap perilaku seseorang bersumber dari dua yaitu atribusi internal dan atribusi eksternal. Atribusi internal adalah tingkah laku yang dipengaruhi dari apa yang melekat didalam diri seseorang dan dikendalikan oleh individu tersebut seperti kepribadian, kesanggupan dan kesadaran. Sedangkan atribusi eksternal adalah tingkah laku yang dipengaruhi oleh faktor yang berasal dari luar individu baik itu dari lingkungan atau situasi maupun tekanan dari individu lain yang memengaruhi individu tersebut dalam berperilaku.

\section{Kepatuhan Wajib Pajak}

Keputusan Menteri Keuangan No.544/KMK.04/2000 menyatakan bahwa kepatuhan perpajakan adalah tindakan wajib pajak dalam pemenuhan kewajiban perpajakannya sesuai 
dengan ketentuan peraturan perundang undangan dan peraturan pelaksanaan perpajakan yang berlaku dalam suatu Negara. Kepatuhan wajib pajak juga dapat diartikan sebagai seorang wajib pajak maupun badan telah menyelenggarakan dan melaksanakan kewajiban sebagai wajib pajak dengan baik dan benar dan tepat dengan waktu yang telah ditetapkan dan yang paling terpenting adalah sesuai dengan aturan perpajakan yang berlaku umum.

\section{Kesadaran Wajib Pajak}

Kesadaran wajib pajak adalah sebuah itikad baik seseorang untuk memenuhi kewajiban perpajakan secara tulus ikhlas tanpa adanya imbalan. Kesadaran memperlihatkan komponen penting seperti pemahaman serta pengetahuan. Apabila dikaitkan dengan kesadaran wajib pajak maka mempunyai makna yaitu seseorang maupun badan yang mempunyai pemahaman serta pengetahuan tentang perpajakan dan bisa mengendalikan diri, sadar akan tugas dan tanggung jawabnya untuk melakukan kewajiban sebagai wajib pajak (Susilawati dan Budiartha, 2013).

\section{Kualitas Pelayanan}

Pelayanan adalah suatu proses bantuan kepada orang lain dengan cara-cara tertentu yang memerlukan kepekaan dan hubungan interpersonal agar terciptanya kepuasaan dan keberhasilan. Pelayanan dalam sektor perpajakan dapat didefinisikan sebagai pelayanan yang diberikan kepada wajib pajak dalam memenuhi kewajiban perpajakan. Salah satu upaya untuk meningkatkan kepatuhan wajib pajak adalah dengan memberikan pelayanan yang baik kepada wajib pajak (Rustiyaningsih, 2011).

\section{Tingkat Penghasilan}

Penghasilan adalah suatu bentuk balas jasa yang diperoleh saat menyelesaikan suatu pekerjaan. Penghasilan adalah suatu hasil yang diterima oleh seseorang atau rumah tangga dari berusaha atau bekerja. Masyarakat mempunyai pekerjaan bermacam ragam, seperti bertani, nelayan, beternak, buruh, serta berdagang dan juga bekerja pada sektor pemerintah dan swasta (Nazir, 2010).

\section{Pengaruh Kesadaran Wajib Pajak Terhadap Kepatuhan Pembayaran Pajak Bumi Bangunan}

Teori atribusi menjelaskan bahwa dalam berperilaku individu dipengaruhi oleh atribusi internal atau eksternal. Kesadaran wajib pajak merupakan atribusi internal yang dapat memengaruhi persepsi dari wajib pajak untuk membuat keputusan mengenai kepatuhan dalam menjalankan kewajiban perpajakannya (Susherdianto dan Haryanto, 2012). Kesadaran wajib pajak meliputi pemahaman serta pengetahuan mengenai peraturan perpajakan. Kesadaran wajib pajak merupakan sebuah perilaku atau sikap wajib pajak yang berasal dari dalam diri seseorang dan berkaitan dengan persepsi yang didalamnya termasuk suatu keyakinan, pengetahuan serta kecenderungan untuk melakukan suatu tindakan yang sesuai dengan dorongan atau motivasi yang diberikan sistem dan ketentuan perpajakan yang berlaku (Fikriningrum, 2012).

Kesadaran wajib pajak dalam melaksanakan kegiatan perpajakan akan berpengaruh terhadap kepatuhan wajib pajak, karena semakin tinggi tingkat kesadaran wajib pajak tersebut maka tingkat kepatuhan wajib pajak terhadap kewajiban atas kegiatan perpajakannya juga akan tinggi. Hal ini didukung oleh penelitian yang dilakukan oleh Takaria dan Siregar (2020) bahwa tingkat kesadaran wajib pajak mempunyai pengaruh terhadap tingkat kepatuhan wajib pajak, berarti semakin tinggi tingkat kesadaran tersebut maka tingkat kepatuhan wajib pajak juga akan tinggi dalam melakukan kewajiban perpajakannya. Hipotesis yang dirumuskan dalam penelitian ini adalah: 
$\mathbf{H}_{1}$ : Kesadaran wajib pajak berpengaruh positif terhadap Kepatuhan Pembayaran Pajak Bumi Bangunan.

\section{Pengaruh Kualitas Pelayanan Terhadap Kepatuhan Pembayaran Pajak Bumi Bangunan}

Teori atribusi menjelaskan bahwa dalam berperilaku, individu dipengaruhi oleh atribusi internal atau eksternal. Kualitas pelayanan yang diberikan fiskus adalah salah satu bentuk atribusi eksternal yang dapat memengaruhi kepatuhan wajib pajak (Purnaditya dan Rohman, 2015). Kualitas pelayanan perpajakan merupakan bagaimana pihak fiskus atau pemungut pajak dalam memberikan pelayanan terhadap wajib pajak. Pelayanan yang dimaksud adalah bagaimana pihak pemungut pajak memberikan pemahaman, pelayanan, dan kemampuan fiskus dalam hal perpajakan yang sesuai dengan aturan perpajakan yang berlaku umum (Mahardika et al, 2015).

Kualitas pelayanan perpajakan yang diberikan kepada wajib pajak akan lebih mengarah kepada patuhnya wajib pajak tersebut dikarenakan pelayanan yang baik dan menimbulkan kenyamanan terhadap wajib pajak dan persepsi wajib pajak terhadap kualitas pelayanan tersebut akan memengaruhi sikap patuh wajib pajak tersebut. Hal ini didukung oleh penelitian Isawati et al (2016) yaitu kualitas pelayanan perpajakan berpengaruh terhadap tingkat kepatuhan wajib pajak. Pelayanan perpajakan yang diberikan mempunyai pengaruh terhadap kepatuhan wajib pajak yaitu semakin tinggi tingkat kepuasan pelayanan perpajakan yang diberikan oleh fiskus maka tingkat kepatuhan wajib pajak dalam melakukan pembayaran pajak juga semakin tinggi. Hipotesis yang dirumuskan dalam penelitian ini adalah:

$\mathbf{H}_{2}$ : Kualitas pelayanan pajak berpengaruh positif terhadap kepatuhan pembayaran pajak bumi bangunan.

\section{Pengaruh Tingkat Penghasilan Terhadap Kepatuhan Pembayaran Pajak Bumi Bangunan}

Teori atribusi menjelaskan bahwa dalam berperilaku individu dipengaruhi oleh atribusi internal atau eksternal. Tingkat penghasilan merupakan atribusi internal yang dapat memengaruhi kepatuhan wajib pajak (Krisna dewi dan Merkusiwati, 2020). Penghasilan diartikan sebagai suatu yang diterima sebagai bentuk balas jasa karena sudah melaksanakan faktor-faktor produksi atas suatu pekerjaan. Penghasilan yang diterima oleh seseorang memengaruhi dari kepatuhan wajib pajak dalam melaksanakan kewajiban perpajakan dikarenakan dalam membayar pajak bersumber dari penghasilan yang dihasilkan oleh wajib pajak tersebut (Sari dan Susanti, 2013).

Apabila seseorang memperoleh penghasilan yang relatif tinggi diasumsikan bahwa ia tidak menemukan kesulitan untuk patuh dalam kewajiban perpajakan, namun apabila tingkat penghasilan rendah maka ia menemukan kesulitan dalam membayar kewajiban perpajakan, dikarenakan adanya pemenuhan kebutuhan ekonomi lainnya yang menyebabkan rendahnya tingkat kepatuhan wajib pajak (Amran, 2018). Hal ini didukung penelitian Ningtyas et al (2020) menunjukkan hasil tingkat penghasilan berpengaruh terhadap kepatuhan wajib pajak dalam membayar PBB. Penghasilan seorang wajib pajak akan memengaruhi apakah wajib pajak tersebut akan patuh ataupun tidak terhadap pembayaran kewajiban perpajakannya. Hal ini berarti semakin tinggi tingkat penghasilan yang diterima atau diperoleh oleh wajib pajak maka tingkat kepatuhan wajib pajak dalam melakukan pembayaran pajak juga akan tinggi, sebaliknya semakin rendah penghasilan wajib pajak maka tingkat kepatuhan wajib pajak dalam memenuhi kewajibannya untuk membayar pajak juga akan rendah. Hipotesis yang dirumuskan dalam penelitian ini adalah: 
$\mathbf{H}_{3}$ : Tingkat Penghasilan berpengaruh positif terhadap Kepatuhan Pembayaran Pajak Bumi Bangunan.

\section{Kerangka Konseptual}

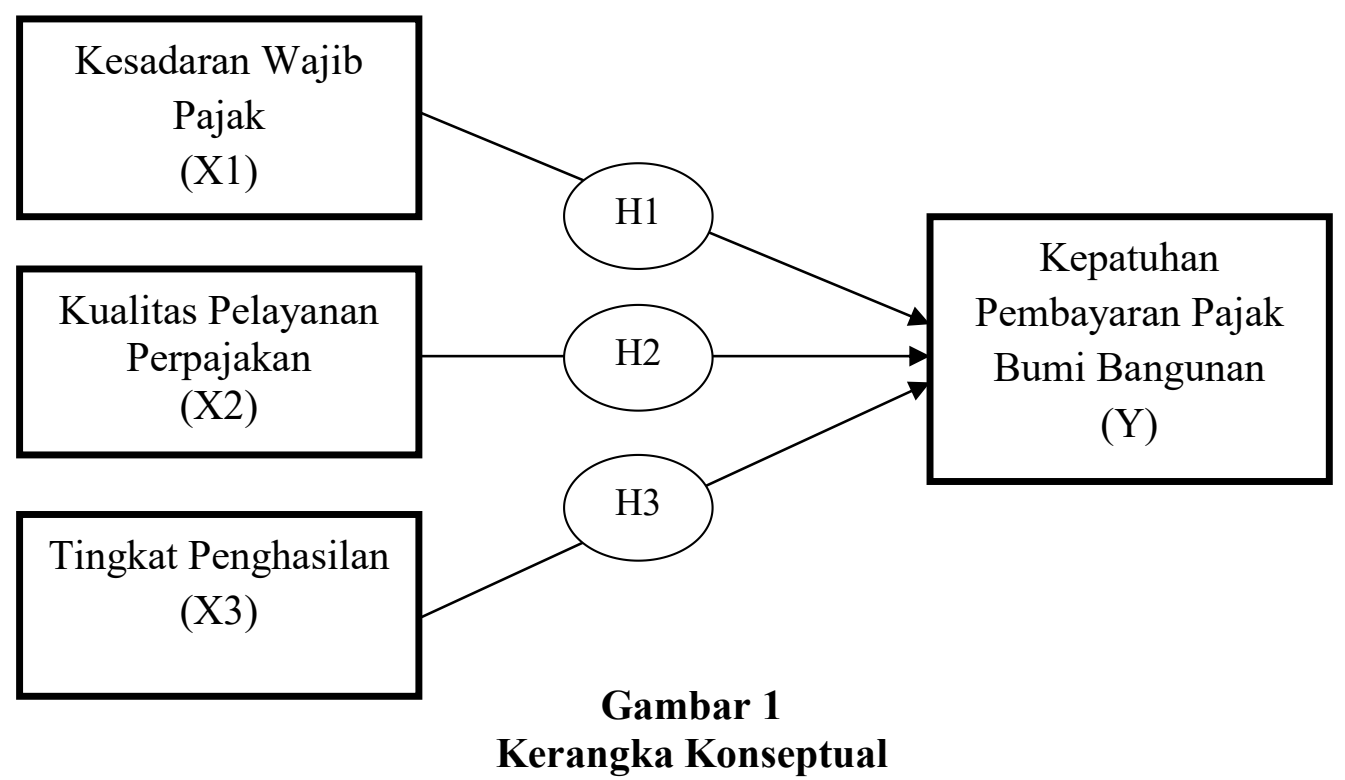

\section{METODE PENELITIAN}

\section{Sampel dan Jenis Penelitian}

Penelitian ini merupakan penelitian deskriptif kuantitatif dengan menggunakan pendekatan survei, yaitu penelitian yang mengambil sampel dari satu populasi menggunakan kuesioner sebagai alat pengumpulan data. Penelitian ini dilakukan di Unit Pelaksana Teknis Dinas Penghasilan, Pengelolaan Keuangan Aset dan Badan Keuangan Daerah Kota Payakumbuh. Populasi penelitian ini adalah seluruh wajib pajak bumi dan bangunan yang terdaftar di UPTD Penghasilan, Pengelolaan Keuangan Aset dan Badan Keuangan Daerah Kota Payakumbuh sebanyak 52.804 wajib pajak pada tahun 2020.

Teknik pengambilan sampel pada penelitian ini dengan metode Convenience Sampling Method yaitu pengambilan anggota sampel dari sebuah populasi yang dilakukan berdasarkan dengan pertemuan secara kebetulan dengan peneliti dan sampel yang digunakan adalah sampel yang sesuai dengan sumber data yang dibutuhkan oleh peneliti (Sugiyono, 2017). Peneliti menggunakan rumus slovin dalam penentuan jumlah sampel dengan tingkat margin of error sebesar $(0,1)$ atau sebesar $10 \%$ dan sampel yang disarankan adalah 100 orang wajib pajak.

\section{Jenis, Sumber dan Teknik Pengumpulan Data}

Penelitian ini menggunakan jenis data primer. Data primer merupakan data yang didapatkan secara langsung oleh peneliti dengan turun kelapangan untuk mendapatkan datanya. Data primer dari penelitian ini didapatkan dengan metode kuesioner. Kuesioner ini akan dibagikan kepada para responden.

\section{Variabel Penelitian dan Pengukuran}

Variabel independen adalah variabel yang dapat mempengaruhi perubahan pada variable dependen dan mempunyai hubungan yang positif maupun negative bagi variabel dependen. Variabel independen yang digunakan dalam penelitian ini adalah kesadaran wajib 
pajak, kualitas pelayanan dan tingkat penghasilan. Variabel dependen adalah variabel yang menjadi perhatian utama dalam sebuah pengamatan. Variabel dependen yang digunakan dalam penelitian ini adalah Kepatuhan wajib pajak.

Semua variabel diatas diukur oleh instrument pengukur dalam bentuk kuesioner yang memenuhi pernyataan tipe skala likert. Untuk setiap pilihan jawaban diberi skor. Skor atas pilihan jawaban untuk kuesioner yang disajikan digambar dalam table berikut:

Tabel 2

Skala Likert

\begin{tabular}{|c|c|c|}
\hline NO & Keterangan & Skor \\
\hline 1 & Sangat Tidak Setuju (STS) & 1 \\
\hline 2 & Tidak Setuju (TS) & 2 \\
\hline 3 & Netral $(\mathrm{N})$ & 3 \\
\hline 4 & Setuju (S) & 4 \\
\hline 5 & Sangat Setuju (SS) & 5 \\
\hline
\end{tabular}

Sumber: Sugiyono (2017).

\section{HASIL DAN PEMBAHASAN}

Deskripsi Responden Penelitian

Penelitian ini dilakukan dengan cara memberikan kuesioner kepada wajib pajak bumi bangunan yang terdaftar di Badan Keuangan Daerah dan UPT Dinas Pendapatan dan Pengelolaan Aset Kota Payakumbuh. Peneliti menyebarkan 100 kuesioner secara langsung kepada responden dan pengambilan kuesioner diterima pada saat itu juga. Dari 100 kuesioner yang disebarkan, 100 kuesioner tersebut diterima kembali dan kuesioner tersebut dapat diolah dan dianalisis. Berikut hasil penyebaran kuesioner yang disajikan dalam tabel berikut :

Tabel 3

Hasil Pembagian Kuesioner

\begin{tabular}{ccc}
\hline Kuesioner yang dibagi & Kuesioner yang kembali & Presentase \\
\hline 100 & 100 & $100 \%$ \\
\hline Sumber : Data olahan peneliti (2021). & &
\end{tabular}

\section{Karakteristik Responden}

Karakteristik responden dalam penelitian ini dikelompokan kedalam beberapa kelompok yaitu jenis kelamin, usia, tingkat pendidikan terakhir dan lamanya menjadi wajib pajak. Deskripsi karakteristik responden disajikan dalam tabel berikut :

Tabel 4

Karakteristik Responden

\begin{tabular}{lll}
\hline Deskripsi Responden & Keterangan & Frekuensi \\
\hline Jenis Kelamin & Laki-Laki & 40 \\
& Perempuan & 60 \\
\hline Usia & $>30$ th & 19 \\
& $30-40$ th & 26 \\
& $>40$ th & 55 \\
\hline Pendidikan Terakhir & SD & 11 \\
& SMP & 12 \\
& SMA & 50 \\
& S1 & 25 \\
& S2/S3 & 2 \\
\hline Tingkat Penghasilan & $<$ Rp 1.000.000 & 11
\end{tabular}




\begin{tabular}{lll} 
Perbulan & $\operatorname{Rp~1.000.000-Rp~3.000.000~}$ & 48 \\
& $\operatorname{Rp~4.000.000-Rp~7.000.000~}$ & 31 \\
& $\operatorname{Rp~8.000.000-Rp~10.000.000~}$ & 7 \\
& $>\operatorname{Rp~10.000.0000~}$ & 3 \\
\hline Lama Wajib Pajak & $1-5$ tahun & 28 \\
& $6-10$ tahun & 15 \\
$11-15$ tahun & 20 \\
& $>15$ tahun & 37 \\
\hline
\end{tabular}

Sumber : Data Olahan Peneliti (2021).

\section{Uji Statistik Deskriptif}

\section{Tabel 5}

Hasil Uji Deskriptif

\begin{tabular}{lccccc}
\hline & $\mathrm{N}$ & Minimum & Maximum & Mean & Std. Deviation \\
\hline Kesadaran_Wajib_Pajak & 100 & 26 & 50 & 38.17 & 5.193 \\
Kualitas_Pelayanan & 100 & 18 & 45 & 32.25 & 6.102 \\
Tingkat_Penghasilan & 100 & 1 & 5 & 2.43 & .891 \\
Kepatuhan_Wajib_Pajak & 100 & 24 & 35 & 28.52 & 2.816 \\
Valid N (listwise) & 100 & & & & \\
\hline
\end{tabular}

Sumber: Data Olahan Peneliti (2021).

Berdasarkan pengujian statistik di atas, dapat diketahui bahwa variabel kesadaran wajib pajak mempunyai nilai minimum sebesar 26, nilai maximum sebesar 50 dan nilai ratarata (mean) sebesar 38,17 dengan standar deviasi bernilai 5,193. Variabel kualitas pelayanan mempunyai nilai minimum sebesar 18 , nilai maximum sebesar 45 dan nilai rata-rata (mean) sebesar 32,25 dengan standar deviasi bernilai 6,102. Variabel tingkat penghasilan mempunyai nilai minimum sebesar 1 , nilai maximum sebesar 5 dan nilai rata-rata (mean) sebesar 2,43 dengan standar deviasi bernilai 0,891 . Variabel kepatuhan wajib pajak mempunyai nilai minimum sebesar 24, nilai maximum sebesar 35 dan nilai rata-rata (mean) sebesar 28,52 dengan standar deviasi bernilai 2,816. Nilai rata-rata dan standar deviasi variabel independen dan dependen pada penelitian ini menunjukkan bahwa terdapat penyebaran data yang baik dikarenakan nilai rata-rata (mean) lebih besar dari nilai standar deviasi.

\section{Uji Kualitas Data}

\section{Uji validitas}

Uji validitas ini digunakan untuk mengukur validnya suatu kuesioner dengan cara membandingkan nilai $r$ hitung dengan $r$ tabel. Pengujian validitas ini menggunakan korelasi bivariate. Hasil pengujian validitas pada tabel berikut :

Tabel 6

Uji Validitas Kesadaran Wajib Pajak

\begin{tabular}{ccccc}
\hline No & Item & R Hitung & R Tabel & Keterangan \\
\hline 1 & $\mathrm{X} 1.1$ & 0,348 & 0,1654 & Valid \\
2 & $\mathrm{X} 1.2$ & 0,389 & 0,1654 & Valid \\
3 & $\mathrm{X} 1.3$ & 0,574 & 0,1654 & Valid \\
4 & $\mathrm{X} 1.4$ & 0,563 & 0,1654 & Valid \\
5 & $\mathrm{X} 1.5$ & 0,297 & 0,1654 & Valid \\
6 & $\mathrm{X} 1.6$ & 0,871 & 0,1654 & Valid \\
7 & $\mathrm{X} 1.7$ & 0,869 & 0,1654 & Valid \\
8 & $\mathrm{X} 1.8$ & 0,664 & 0,1654 & Valid \\
9 & $\mathrm{X} 1.9$ & 0,855 & 0,1654 & Valid \\
10 & $\mathrm{X} 1.10$ & 0,870 & 0,1654 & Valid \\
\hline
\end{tabular}


Kualitas Pelayanan

\begin{tabular}{ccccc}
\hline No & Item & R Hitung & R Tabel & Keterangan \\
\hline 1 & X2.1 & 0,738 & 0,1654 & Valid \\
2 & $\mathrm{X} 2.2$ & 0,849 & 0,1654 & Valid \\
3 & $\mathrm{X} 2.3$ & 0,875 & 0,1654 & Valid \\
4 & $\mathrm{X} 2.4$ & 0,769 & 0,1654 & Valid \\
5 & $\mathrm{X} 2.5$ & 0,817 & 0,1654 & Valid \\
6 & $\mathrm{X} 2.6$ & 0,858 & 0,1654 & Valid \\
7 & $\mathrm{X} 2.7$ & 0,865 & 0,1654 & Valid \\
8 & $\mathrm{X} 2.8$ & 0,734 & 0,1654 & Valid \\
9 & $\mathrm{X} 2.9$ & 0,759 & 0,1654 & Valid \\
\hline & & Tingkat Penghasilan & Keterangan \\
\hline No & Item & R Hitung & R Tabel & Valid \\
\hline 1 & X3.1 & 1,000 & 0,1654 & Keterangan \\
\hline & & Kepatuhan Wajib Pajak & Valid \\
\hline No & Item & R Hitung & R Tabel & Valid \\
\hline 1 & Y1.1 & 0,512 & 0,1654 & Valid \\
2 & Y1.2 & 0,623 & 0,1654 & Valid \\
3 & Y1.3 & 0,603 & 0,1654 & Valid \\
4 & Y1.4 & 0,599 & 0,1654 & Valid \\
5 & Y1.5 & 0,577 & 0,1654 & 0,1654 \\
6 & Y1.6 & 0,612 & 0,1654 & \\
7 & Y1.7 & 0,556 & & \\
\hline
\end{tabular}

Sumber: Data Olahan Peneliti (2021).

Berdasarkan uji validitas di atas menunjukkan bahwa masing-masing item pertanyaan yang ada di dalam kuesioner adalah valid. Hal ini dapat ditentukan berdasarkan nilai dari $\mathrm{r}_{\text {hitung }}$ lebih besar dari $r_{\text {tabel }}$ dan nilai sig kecil dari 0,05 , maka item pertanyaan dapat dikatakan valid.

\section{Uji Realibilitas}

Uji reliabilitas digunakan untuk melihat apakah hasil dari kuesioner dapat konsisten dan dipercaya. Adapun hasil uji reliabilitas yang diperoleh dari penelitian ini sebagai berikut:

Tabel 7

Uji Reliabilitas

\begin{tabular}{lccc}
\hline \multicolumn{1}{c}{ Variabel } & Cronbach Alpha & Nilai Kritis & Keterangan \\
\hline Kesadaran WP & 0,858 & 0,60 & Reliabel \\
Kualitas Pelayanan & 0,932 & 0,60 & Reliabel \\
Tingkat Penghasilan & 1,000 & 0,60 & Reliabel \\
Kepatuhan WP & 0,667 & 0,60 & Reliabel \\
\hline
\end{tabular}

Sumber: Data Olahan Peneliti (2021).

Berdasarkan uji reabilitas di atas menunjukkan nilai Cronbach's Alpha semua variabel besar dari 0,60. Hasil tersebut menunjukkan bahwa semua variabel yang ada di dalam penelitian ini dinyatakan reliabel. Hal ini berarti bahwa semua jawaban yang diberikan oleh para responden sudah konsisten dalam menjawab setiap butir pertanyaan-pertanyaan yang digunakan dalam penelitian ini.

\section{Uji Asumsi Klasik}

\section{Uji Normalitas}

Uji normalitas bertujuan untuk menguji apakah di dalam model regresi, variabel dependen maupun independen memiliki distribusi normal atau tidak. Uji normalitas mempunyai hasil sebagai berikut: 
Tabel 8

Uji Normalitas

\begin{tabular}{llr}
\hline & & $\begin{array}{c}\text { Unstandardized } \\
\text { Residual }\end{array}$ \\
\hline$N$ & Mean & 100 \\
Normal Parameters ${ }^{a, b}$ & Std. & .0000000 \\
& Deviation & 1.59825778 \\
Most Extreme & Absolute & \\
Differences & Positive & .076 \\
Test Statistic & Negative & .076 \\
Asymp. Sig. (2-tailed) & & -.076 \\
Sumber: Data Olahan Peneliti (2021). & .076 \\
\end{tabular}

Sumber: Data Olahan Peneliti (2021).

Berdasarkan dari uji normalitas yang dilakukan peneliti menggunakan KolmogrovSmirnov Test diperoleh nilai sebesar 0,076 dan Asymp.Sig 0,166 lebih besar dari 0,05. Dapat disimpulkan bahwa data terdistribusi secara normal, dan data tersebut memenuhi persyaratan untuk melakukan uji regresi linear berganda.

\section{Uji Multikolinearitas}

Uji multikolinearitas bertujuan untuk menguji apakah dalam suatu model regresi ditemukan adanya korelasi antara variabel independen atau tidak. Regresi terbebas dari permasalahan multikolinearitas apabila $\mathrm{VIF}<10$ dan nilai tolerance $>0,10$.

Tabel 9

Uji Multikolinearitas

\begin{tabular}{ccc}
\hline \multirow{2}{*}{ Model } & \multicolumn{2}{c}{ Collinearity Statistics } \\
\cline { 2 - 3 } & Tolerance & VIF \\
X1 & 0,738 & 1,354 \\
X2 & 0,713 & 1,402 \\
X3 & 0,903 & 1,108 \\
\hline
\end{tabular}

Sumber : Data Olahan Peneliti (2021).

Bedasarkan uji multikolinearitas di atas menunjukkan bahwa hasil dari uji multikolinearitas yang dilakukan dalam penelitian ini yaitu dengan melihat nilai tolerance dan VIF. Nilai tolerance semua variabel independen lebih besar dari 0,10, sedangkan nilai $V I F$ semua variabel yang tertera didalam tabel menunjukkan bahwa nilai VIF kecil dari 10 . Hal ini dapat disimpulkan bahwa tidak terjadi adanya gejala multikolinearitas antara variabel independen dalam model regresi.

\section{Uji Heteroskedastisitas}

Uji heteroskedastisitas dilakukan untuk menguji apakah variasi residual absolut sama atau tidak untuk semua pengamatan yang dapat dilihat dari tabel berikut:

Tabel 10

Uji Heteroskedastisitas

\begin{tabular}{cc}
\hline Model & Sig. \\
\hline X1 & 0,254 \\
X2 & 0,342 \\
X3 & 0,920 \\
\hline
\end{tabular}

Sumber: Data Olahan Peneliti (2021). 
Berdasarkan uji heteroskedastisitas di atas diperoleh nilai semua variabel independen dalam penelitian ini lebih besar dari 0,05 . Hal ini dapat disimpulkan bahwa dalam penelitian ini tidak terdapat permasalahan heteroskedastisitas antara variabel independen dalam model regresi.

\section{Model Regresi Linear Berganda}

Uji regresi linear berganda dimaksudkan untuk mengetahui pengaruh dari variabelvariabel independen $(\mathrm{X})$ terhadap variabel dependen $(\mathrm{Y})$. Berikut hasil dari output data regresi linear berganda:

\section{Tabel 11}

Uji Regresi Linear Berganda

\begin{tabular}{|c|c|c|c|c|c|c|}
\hline \multirow[b]{2}{*}{ Model } & & \multicolumn{2}{|c|}{ Unstandardized Coefficients } & \multirow{2}{*}{$\begin{array}{r}\text { Standardized } \\
\text { Coefficients } \\
\text { Beta }\end{array}$} & \multirow[b]{2}{*}{$T$} & \multirow[b]{2}{*}{ Sig. } \\
\hline & & $B$ & Std. Error & & & \\
\hline \multirow{4}{*}{1} & (Constant) & 18.028 & 1.251 & & 14.112 & .000 \\
\hline & $\mathrm{X} 1$ & .127 & .037 & .301 & 3.462 & .001 \\
\hline & $\mathrm{X} 2$ & .155 & .032 & .433 & 4.900 & .000 \\
\hline & $\mathrm{X} 3$ & .271 & .193 & .111 & 1.408 & .162 \\
\hline
\end{tabular}

a. Dependent Variable: Y

Sumber: Data Olahan Peneliti (2021).

Berdasarkan dari uji regresi linear berganda yang telah diolah dengan bantuan program SPSS ver. 25, maka didapat peroleh hasil perhitungan sebagai berikut:

$$
Y=18,028+0,127 \times 1+0,155 X 2+0,271 X 3
$$

Berdasarkan hasil perhitungan regresi di atas nilai konstanta bernilai 18,028. Hal ini menunjukkan bahwa jika variabel independen diasumsikan bernilai nol, maka variabel dependen sebesar 18,028. Hal ini berarti kesadaran wajib pajak, kualitas pelayanan dan tingkat pelayanan terhadap kepatuhan wajib pajak bumi dan bangunan adalah sebesar 18,028.

Koefisien regresi variabel kesadaran wajib pajak bernilai positif 0,127 . Hal ini menyatakan bahwa apabila kesadaran wajib pajak ditingkatkan satu-satuan maka akan menaikkan variabel kepatuhan wajib pajak bumi dan bangunan sebesar 0,127 satuan dengan catatan bahwa variabel bebas yang lain dari model regresi adalah tetap. Koefisien regresi variabel kualitas pelayanan bernilai positif 0,155 . Hal ini menyatakan bahwa apabila kualitas pelayanan ditingkatkan satu-satuan maka akan menaikkan variabel kepatuhan wajib pajak bumi dan bangunan sebesar 0,155 satuan dengan catatan bahwa variabel bebas yang lain dari model regresi adalah tetap. Koefisien regresi variabel tingkat penghasilan bernilai positif 0,271 . Hal ini menyatakan bahwa apabila tingkat penghasilan ditingkatkan satu-satuan maka akan menaikkan variabel kepatuhan wajib pajak bumi dan bangunan sebesar 0,271 satuan dengan catatan bahwa variabel bebas yang lain dari model regresi adalah tetap.

\section{Uji Hipotesis}

Uji t

Pengujian pada hipotesis dalam penelitian ini menggunakan uji statistik t. Uji t dilakukan dengan menggunakan bantuan dari aplikasi SPSS ver. 25. berdasarkan tabel 11 di atas dapat dilihat pengujian hipotesis dengan melihat nilai signifikansi pada variabel kesadaran wajib pajak adalah sebesar 0,001 dengan demikian nilai signifikansi lebih kecil dari 0,05 . Hal ini dapat diartikan bahwa variabel kesadaran wajib pajak berpengaruh terhadap kepatuhan pembayaran pajak bumi dan bangunan. Variabel kualitas pelayanan mempunyai 
nilai signifikansi sebesar 0,000 , dengan demikian nilai signifikansi lebih kecil dari 0,05 . Hal ini dapat diartikan bahwa variabel kualitas pelayanan berpengaruh terhadap kepatuhan pembayaran pajak bumi dan bangunan. Variabel tingkat penghasilan mempunyai nilai signifikansi sebesar 0,162, dengan demikian nilai signifikansi lebih besar dari 0,05. Hal ini dapat diartikan bahwa variabel tingkat penghasilan tidak berpengaruh terhadap kepatuhan pembayaran pajak bumi dan bangunan.

\section{Uji F}

Uji F digunakan untuk menguji apakah model yang digunakan signifikan atau tidak. Uji $F$ dilakukan untuk memastikan apakah model tersebut dapat digunakan untuk memprediksi dari pengaruh variabel independen secara bersama-sama terhadap variabel dependen.

\begin{tabular}{ccccccc}
\multicolumn{7}{c}{ Tabel 12 } \\
\multicolumn{1}{c}{ Uji F } \\
\hline & Model & Sum of & & & \\
& Squares & $d f$ & Mean Square & F & Sig. \\
\hline \multirow{2}{*}{1} & Regression & 220.072 & 3 & 73.357 & 27.847 & .000 \\
& Residual & 252.888 & 96 & 2.634 & & \\
& Total & 471.960 & 99 & & & \\
\hline
\end{tabular}

Sumber: Data Olahan Peneliti (2021).

Berdasarkan uji $\mathrm{F}$ di atas diperoleh nilai signifikansi sebesar 0.000 kecil dari 0,05 dan nilai $\mathrm{F}$ hitung sebesar 27,847 lebih besar dari nilai $\mathrm{F}$ tabel yaitu sebesar 2,70. Hal ini dapat dijelaskan bahwa variabel independen yaitu kesadaran wajib pajak, kualitas pelayanan dan tingkat penghasilan secara simultan atau secara bersama-sama memengaruhi dari variabel dependen yaitu kepatuhan pembayaran pajak bumi dan bangunan. Hal ini berarti bahwa banyak sedikitnya kepatuhan pembayaran pajak bumi bangunan dipengaruhi oleh kesadaran wajib pajak, kualitas pelayanan dan tingkat penghasilan.

\section{Uji Koefisien Determinasi $\left(\mathbf{R}^{2}\right)$}

Uji koefisien determinasi $\left(\mathrm{R}^{2}\right)$ digunakan untuk mengukur seberapa jauh kemampuan model dalam menjelaskan variasi variabel dependen. Hasil uji koefisien determinasi sebagai berikut:

Tabel 13

Uji Koefisien Determinasi

\begin{tabular}{lcccr}
\hline $\begin{array}{l}\text { Mod } \\
\mathrm{el}\end{array}$ & $R$ & $R$ Square & $\begin{array}{c}\text { Adjusted } R \\
\text { Square }\end{array}$ & $\begin{array}{l}\text { Std. Error of } \\
\text { the Estimate }\end{array}$ \\
\hline 1 & .682 & .465 & .449 & 1.623 \\
\hline \multicolumn{2}{l}{ Sumber: Data Olahan Peneliti (2021). }
\end{tabular}

Berdasarkan uji koefisien determinasi di atas diketahui nilai adjust $R^{2}$ adalah 0,449 . Hal ini menunjukkan variabel independen yaitu kesadaran wajib pajak, kualitas pelayanan, tingkat penghasilan memengaruhi sebesar $44,09 \%$ variabel dependen yaitu kepatuhan wajib pajak dalam pembayaran pajak bumi dan bangunan, sedangkan sisanya sebesar $55,1 \%$ dipengaruhi oleh faktor lain yang tidak diteliti dan tidak termasuk dalam model penelitian ini.

\section{Pengaruh Kesadaran Wajib Pajak Terhadap Kepatuhan Pembayaran Pajak Bumi Bangunan.}

Nilai signifikansi varibel kesadaran wajib pajak adalah sebesar 0,001 lebih kecil dari 0,05. Hal ini dapat disimpulkan bahwa terdapat pengaruh kesadaran wajib pajak dalam 
meningkatkan kepatuhan wajib pajak dalam pembayaran pajak bumi dan bangunan. Teori atribusi menyatakan bahwa motif yang didasari oleh suatu individu untuk bertindak atau berperilaku bisa disebabkan oleh faktor internal maupun eksternal. Kesadaran wajib pajak merupakan atribusi internal yang dapat memengaruhi persepsi dari wajib pajak untuk membuat keputusan mengenai kepatuhan dalam menjalankan kewajiban perpajakannya. Hasil pada penelitian ini memberikan bukti bahwa teori atribusi dapat menjelaskan sikap wajib pajak yang berasal dari atribusi internal yaitu kesadaran wajib pajak dan teori ini mendukung bahwa kesadaran wajib pajak memengaruhi kepatuhan wajib pajak.

Kesadaran yang dimiliki oleh wajib pajak akan memengaruhi wajib pajak untuk berperilaku patuh atau tidak patuh setelah mereka mengetahui hasil yang akan didapat ketika mereka memutuskan untuk melakukan atau tidak melakukan dalam membayar pajak yang sangat penting untuk membantu dalam pembangunan negara. Semakin tinggi tingkat kesadaran yang dimiliki oleh wajib pajak, maka semakin besar pula keyakinan yang dimilikinya akan hasil yang akan didapat dari sikap patuh yang ditimbulkan. Kesadaran yang dimiliki oleh wajib pajak akan menyebabkan wajib pajak mengetahui fungsi penting perpajakan, dari hasil ini dapat dijadikan evaluasi serta informasi untuk bertindak dan mengambil keputusan untuk bersikap patuh atau tidak patuh.

Menurut Diva (2019) kesadaran wajib pajak mempunyai pengaruh terhadap peningkatan kepatuhan pembayaran pajak. Hal ini sejalan dengan hasil penelitian yang dilakukan oleh Takaria dan Siregar (2020) dan Rahman (2018) bahwa kesadaran wajib pajak berpengaruh terhadap kepatuhan pembayaran pajak bumi bangunan. Hal ini berarti bahwa semakin tinggi tingkat kesadaran wajib pajak maka akan diikuti dengan tingginya kepatuhan wajib pajak dalam melakukan pembayaran pajak bumi bangunan.

\section{Pengaruh Kualitas Pelayanan Terhadap Kepatuhan Pembayaran Pajak Bumi Bangunan.}

Nilai signifikansi varibel kualitas pelayanan adalah sebesar 0,000 lebih kecil dari 0,05. Hal ini dapat disimpulkan bahwa tidak terdapat pengaruh kualitas pelayanan dalam meningkatkan kepatuhan wajib pajak dalam pembayaran pajak bumi dan bangunan. Teori atribusi menyatakan bahwa motif yang didasari oleh suatu individu untuk bertindak atau berperilaku bisa disebabkan oleh faktor internal maupun eksternal. Kualitas pelayanan merupakan atribusi eksternal yang dapat memengaruhi persepsi dari wajib pajak untuk membuat keputusan mengenai kepatuhan dalam menjalankan kewajiban perpajakannya. Hasil pada penelitian ini memberikan bukti bahwa teori atribusi dapat menjelaskan sikap wajib pajak yang berasal dari atribusi eksternal yaitu kualitas pelayanan dan teori ini tidak mendukung kualitas pelayanan untuk meningkatkan kepatuhan wajib pajak..

Kualitas pelayanan yang diberikan oleh pihak fiskus kepada wajib pajak mempengaruhi tingkat kepatuhan pembayaran pajak. Hal ini berarti bahwa pelayanan perpajakan yang bagus dan memadai yang diberikan oleh pihak fiskus mampu mendorong sikap patuh dari wajib pajak untuk melakukan pembayaran pajak. Ketika adanya kepuasan yang dirasakan oleh wajib pajak selama membayar pajak menimbulkan adanya keyakinan akan harapan yang didapatkan wajib pajak dari pelayanan yang diberikan oleh petugas pajak, sehingga menimbulkan tingginya motivasi wajib pajak untuk berperilaku patuh. Menurut Zainuddin (2018) dengan adanya pelayanan yang baik dari petugas pajak, sistem perpajakan yang efisien dan efektif, serta penyuluhan-penyuluhan pajak yang memberikan motivasi kepada wajib pajak agar taat pajak, akan membuat wajib pajak memiliki keyakinan untuk melaksanakan kewajiban perpajakannya. Hasil ini selaras dengan penelitian yang dilakukan oleh Ermawati \& Parera (2017) dan Awaluddin \& Tamburaka (2017) bahwa bahwa kualitas pelayanan pajak berpengaruh terhadap kepatuhan wajib pajak. 


\section{Pengaruh Tingkat Penghasilan Terhadap Kepatuhan Pembayaran Pajak Bumi Bangunann.}

Nilai signifikansi varibel tingkat penghasilan adalah sebesar 0,162 lebih besar dari 0,05. Hal ini dapat disimpulkan bahwa tidak terdapat pengaruh tingkat penghasilan dalam meningkatkan kepatuhan wajib pajak dalam pembayaran pajak bumi dan bangunan. Teori atribusi menyatakan bahwa motif yang didasari oleh suatu individu untuk bertindak atau berperilaku bisa disebabkan oleh faktor internal maupun eksternal. Tingkat penghasilan merupakan atribusi internal yang dapat memengaruhi persepsi dari wajib pajak untuk membuat keputusan mengenai kepatuhan dalam menjalankan kewajiban perpajakannya. Hasil pada penelitian ini memberikan bukti bahwa teori atribusi tidak dapat menjelaskan sikap wajib pajak yang berasal dari atribusi internal yaitu tingkat penghasilan dan teori ini mendukung bahwa tingkat penghasilan memengaruhi kepatuhan wajib pajak.

Tingkat penghasilan wajib pajak tidak berhubungan dalam memengaruhi wajib pajak untuk melaksanakan kewajiban perpajakannya. Hal ini menunjukan wajib pajak tidak bergantung kepada tingkat penghasilan untuk membayar pajak bumi bangunan, dikarenakan dalam pembayaran pajak bumi bangunan tidak berdasarkan penghasilan wajib pajak tetapi berdasarkan luas tanah dan bangunan yang dimiliki. Menurut Khoirul Mustofa (2011) penghasilan wajib pajak tinggi tidak diikuti dengan peningkatan kepatuhan wajib pajak dalam pembayaran pajak. Hal ini sejalan dengan hasil penelitian yang dilakukan oleh Nasirin (2018) yang menunjukan hasil bahwa tingkat penghasilan tidak mempunyai pengaruh terhadap kepatuhan pembayaran pajak oleh wajib pajak.

\section{SIMPULAN, KETERBATASAN DAN SARAN Simpulan}

Berdasarkan hasil analisis dan pembahasan pada bab sebelumnya, maka dapat disimpulkan sebagai berikut: (1) Kesadaran wajib pajak secara parsial mempunyai pengaruh positif dan signifikan terhadap kepatuhan pembayaran pajak bumi bangunan di Kota Payakumbuh. (2) Kualitas pelayanan mempunyai pengaruh positif dan signifikan terhadap kepatuhan pembayaran pajak bumi bangunan di Kota Payakumbuh. (3) Tingkat penghasilan tidak berpengaruh terhadap kepatuhan pembayaran pajak bumi bangunan di Kota Payakumbuh. Hasil penelitian ini didukung teori atribusi yaitu dalam berperilaku, individu dalam bertindak atau mengambil keputusan dipengaruhi oleh faktor internal dan eksternal. Atribusi internal yang terdiri dari kesadaran wajib pajak didukung oleh teori atribusi, sedangkan tingkat penghasilan tidak didukung oleh teori atribusi. Atribusi eksternal (kualitas pelayanan) didukung oleh teori atribusi. Hal ini dapat memberikan gambaran dan pemahaman yaitu tidak semua faktor internal dapat memengaruhi individu dalam membuat keputusan dan bertindak, sedangkan faktor eksternal yang berasal dari luar diri individu tersebut dapat memengaruhi keputusan dan tindakan yang diambil.

\section{Keterbatasan}

Adapun keterbatasan dalam penelitian ini yang harus diperhatikan oleh peneliti selanjutnya apabila melakukan penelitian mengenai permasalahan kepatuhan wajib pajak adalah peneliti masih belum mampu dalam menjangkau seluruh wajib pajak bumi dan bangunan yang ada di Kota Payakumbuh. Penelitian ini hanya menggunakan tiga variabel bebas yaitu kesadaran wajib pajak, kualitas pelayanan dan tingkat penghasilan, padahal masih banyak faktor atau variabel lain yang relevan dan bisa digunakan. Hasil uji koefisien determinasi diperoleh Adjusted R2 sebesar 0,449 atau sebesar 44,9\% dipengaruhi oleh kesadaran wajib pajak, tingkat penghasilan dalam memengaruhi kepatuhan pembayaran pajak bumi dan bangunan. Sedangkan sisanya $55,1 \%$ dipengaruhi oleh faktor lain yang tidak termasuk dalam model penelitian ini. 


\section{Saran}

Berdasarkan dari hasil penelitian, pembahasan serta kesimpulan di atas, maka peneliti mengajukan saran-saran sebagai berikut: (1) Penelitian selanjutnya diharapkan dapat menggunakan teknik pengambilan sampel yang berbeda, yaitu dengan menggunakan teknik cluster sampling yaitu teknik penentuan sampel berdasarkan wilayah atau area yang digunakan untuk menentukan sampel dari objek yang luas, agar menemukan variasi dari penelitian dan dapat menjangkau lebih luas wajib pajak bumi dan bangunan pada satu wilayah atau area. (1) Penelitian selanjutnya menggunakan variabel bebas lainnya yang tidak digunakan pada penelitian ini seperti religiusitas, usia, jenis kelamin, tingkat pendidikan, sistem regulasi perpajakan, sanksi perpajakan dan variabel lain yang dianggap relevan.

\section{DAFTAR PUSTAKA}

Amran, A. (2018). Pengaruh Sanksi Perpajakan, Tingkat Penghasilan dan Kesadaran Wajib Pajak terhadap Kepatuhan Wajib Pajak Orang Pribadi. Jurnal Ilmiah Akuntansi.

Awaluddin, I., \& Tamburaka, S. (2017). The Effect of Service Quality and Taxpayer Satisfaction on Compliance Payment Tax Motor Vehicles at Office One Roof System in Kendari. The International Journal of Engineering and Science, Vol 6 No 11.

Asriyani, Yennita dan Karona Cahya Susena. (2016). Faktor-Faktor Yang Mempengaruhi Kepatuhan Wajib Pajak Bumi dan Bangunan Di Kecamatan Teluk Segara Kota Bengkulu.

Budhiartama, I Gede Prayuda dan I Ketut Jati. (2016). Pengaruh Sikap, Kesadaran Wajib Pajak dan Pengetahuan Perpajakan pada Kepatuhan Membayar Pajak Bumi dan Bangunan. E-Jurnal Akuntansi Universitas Udayana. Vo1.5 No.2 ISSN: 1510-1535.

Endaryanti Novi Ratih. (2017). Pengaruh Kualitas Pelayanan, Sanksi Perpajakan,Biaya Kepatuhan Pajak, Penerapan E-Filing Dan Pengetahuan Pajak Terhadap Kepatuhan Wajib Pajak (Studi Empiris Pada Kpp Pratama Surakarta). Jurnal Ekonomi dan Bisnis.

Ezer, E. dan Ghozali. (2017). Pengaruh Tingkat Penghasilan, Tarif Pajak, Denda Pajak, Dan Probabilitas Pemeriksaan Pajak Terhadap Kepatuhan Pajak. E-jurnal Akuntansi Universitas Diponegoro: Vol. 6(2).

Fikriningrum, Winda Kurnia. (2012). Analisis Faktor-Faktor Yang Mempengaruhi Wajib Pajak Orang Pribadi Dalam Memenuhi Kewajiban Membayar Pajak (Studi Kasus Pada Kantor Pelayanan Pratama Semarang Candisari).

Haswindar. (2016). Pengaruh Tingkat Penghasilan, Pengetahuan, Dan Kesadaran Wajib Pajak Terhadap Kepatuhan Membayar Pajak Bumi Dan Bangunan Di Kecamatan Pammana Kabupaten Wajo. Jurnal Akuntansi.

Isawati, Tri. (2016). Pengaruh Tingkat Pendapatan, Pengetahuan Perpajakan, Pelayanan Pajak serta Sanksi Pajak Terhadap Kepatuhan Wajib Pajak dalam Membayar Pajak Bumi dan Bangunan. Skripsi. Universitas 17 Agustus 1945 Samarinda.

Keputusan Menteri Keuangan Nomor: 544/KMK. 04/2000 Tentang Kriteria Wajib Pajak yang Dapat Diberikan Pengembalian Pendahuluan Kelebihan Pembayaran Pajak Menteri Keuangan Republik Indonesia.

Lydiana. (2018). Pengaruh Kesadaran Wajib Pajak, Pengetahuan Pajak, dan Sanksi Pajak terhadap Kepatuhan Wajib Pajak Orang Pribadi Di KPP Pratama Surabaya Gubeng. Jurnal Ilmiah Mahasiswa Universitas Surabaya .Vol. 7 No.1.

Mahardika, I Gusti Ngurah Putra et al. 2015. Pengaruh Kualitas Pelayanan Dan Sikap Wajib Pajak Terhadap Kepatuhan Pelaporan Wajib Pajak Orang Pribadi Di Kpp Pratama Singaraja. Jurnal Pendidikan Ekonomi Undiksha: Vol. 5(1).

Muliari, Ni Ketut dan Putu Ery Setiawan. (2011). Pengaruh Persepsi Tentang Sanksi Perpajakan dan Kesadaran Wajib Pajak Pada Kepatuhan Pelaporan Wajib Pajak 
Orang Pribadi Di Kantor Pelayanan Pajak Pratama Depansar Timur. Jurnal Akuntansi dan Bisnis, Volume 2.

Nasirin. (2018). Pengaruh Penghasilan, Kesadaran, dan Pemahaman Wajib Pajak Terhadap Kepatuhan Wajib Pajak Dalam Membayar Pajak Bumi Dan Bangunan (PBB). Jurnal Ekobis Dewantara: Vol. 1 No. 4 April 2018.

Ningsih, H. dan Sri Rahayu. (2015). Pengaruh Kemanfaatan Npwp, Pemahaman Wajib Pajak, Kualitas Pelayanan Dan Sanksi Perpajakan Terhadap Kepatuhan Wajib Pajak Di KPP Pratama Medan Kota. Disertasi. Sumatera Utara: Universitas Islam Sumatera Utara.

Ningtias, Puji Lestari et al. (2020). Kepatuhan Wajib Pajak Membayar PBB: Studi Empiris Kecamatan Arut Selatan. MAKSIMUM: Media Akuntansi Universitas Muhammadiyah Semarang. Vol. 10(2).

Nisa, I. C., \& Umar, M. (2019). Pengaruh Sistem Pemungutan Pajak, Pelayanan Fiskus dan Efektifitas Sistem Perpajakan Terhadap Kepatuhan Wajib Pajak Dengan Layanan Drive Thru Sebagai Variabel Moderating. 53 Journal of Chemical Information and Modeling.

Pravasanti, Yuwita Ariessa. (2020). Analisis Faktor-Faktor yang Mempengaruhi Kepatuhan Wajib Pajak dalam Membayar Pajak Bumi dan Bangunan. Jurnal Akuntansi dan Pajak. Vol. 21(1).

Purnaditya, R. R dan Rohman, A. (2015). Pengaruh pemahaman pajak, kualitas pelayanan dan sanksi pajak terhadap kepatuhan pajak (Studi empiris pada WP OP yang melakukan kegiatan usaha di KPP Pratama Semarang Candisari).

Rahayu, Siti Kurnia. (2010). Perpajakan Indonesia. Yogyakarta: Graha Ilmu.

Rahman, A. (2018). Pengaruh kesadaran wajib pajak, tingkat pendidikan dan pendapatan terhadap kepatuhan dalam membayar pajak bumi dan bangunan. Jurnal Akuntansi, 6(1), 1-19.

Rustiyaningsih, Sri. (2011). Faktor-Faktor Yang Mempengaruhi Kepatuhan Wajib Pajak.

Santika, Kadek Adi. (2015). "Pengaruh Kesadaran Wajib Pajak, Kualitas Pelayanan, dan Sanksi Perpajakan pada Kepatuhan Wajib Pajak Air Tanah di Dinas Pendapatan Kota Denpasar". E-Jurnal Akuntansi . Vol. 12 No. 3.

Sari, R.A. Vivi Yulian dan Neri Susanti. (2013). Faktor-Faktor Yang Mempengaruhi Kepatuhan Wajib Pajak Dalam Membayar Pajak Kendaraan Bermotor (PKB) Di Unit Pelayanan Pendapatan Provinsi (UPPP) Kabupaten Seluma.

Septriani. S. D. (2015). Pengaruh Pelayanan, Sanksi, dan Kesadaran Wajib Pajak Terhadap Kepatuhan Wajib Pajak Orang Pribadi Di KPP Pratama Merauke. Jurnal Ilmu Ekonomi \& Sosial: Volume Vi No. 1, April 2015.

Sugiyono. (2017). Metode Penelitian Kuantitatif, Kualitatif, dan R\&D. Bandung : Alfabeta, $\mathrm{CV}$.

Susherdianto, Rommy dan Haryanto. (2012). Analisis Faktor-Faktor Yang Mempengaruhi Tingkat Kepatuhan Wajib Pajak (Studi WPOP Yang Memiliki Usaha Di Kota Kudus). Diponegoro Journal of Accounting: Vol. 1(1).

Susilawati, Ketut Evi dan Ketut Budiartha. (2013). Pengaruh Kesadaran Wajib Pajak, Pengetahuan Pajak, Sanksi Perpajakan dan Akuntabilitas Pelayanan Publik Pada Kepatuhan Wajib Pajak Kendaraan Bermotor. E-Jurnal Akuntansi Universitas Udayana: Vol. 4(2).

Takaria, Zifora Yanesya, dan Lorina Siregar. (2020). Pengaruh Kesadaran Wajib Pajak Terhadap Kepatuhan Wajib Pajak Bumi Dan Bangunan Di Kota Jakarta. Jurnal Ekonomis 13 (4b). 
Tulenan, Rudolof A, dkk. (2017). Pengaruh Kesadaran Wajib Pajak, Kualitas Pelayanan Fiskus, dan Sanksi Pajak terhadap Kepatuhan Wajib Pajak Orang Pribadi di KPP Pratama Bitung. Jurnal Riset Akuntansi Going Concern.

Yusnindar, Johan et al. (2015). Pengaruh Faktor-Faktor Yang Mempengaruhi Kepatuhan Wajib Pajak Dalam Melakukan Pembayaran Pajak Bumi Dan Bangunan Perdesaan Dan Perkotaan (Studi Pada Wajib Pajak Pbb-P2 Kecamatan Jombang Kabupaten Jombang).

Zainuddin. (2018). Pengetahuan Dan Pemahaman Aturan Perpajakan, Kualitas Pelayanan Dan Persepsi Atas Efektivitas Sistem Perpajakan Terhadap Kemauan Membayar Pajak Dengan Kesadaran Membayar Pajak Sebagai Variabel Intervening. Jurnal Akuntansi Netral, Akuntabel, Objektif, Vol.1(1): 14-32. 